\title{
IMPROVING INDIANA'S MANDATORY IMMUNIZATION Programs
}

\author{
Matt Lasher*
}

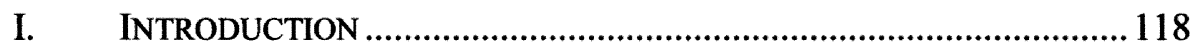

II. THE PURPOSES FOR AND CONSIDERATIONS OF MANDATORY

VACCINATION PROGRAMS

A. The Health and Socio-economic Impacts of Communicable and

Infectious Diseases.

B. The Rise of Vaccination: The Reduction and Elimination of Endemic Diseases

C. Remaining VPD Risks Compel Continuation of Universal Immunizations.

D. Increasing Numbers of Parents Resist Childhood

Immunizations

1. The Inherent Risks of Vaccinations

2. Addressing the risks: using risk balancing to design vaccination programs

3. Misunderstanding the relative risks: are parents afraid of the right threats?

E. The Harms of Mandatory Vaccination Exemptions: the Problem

of the Commons.

1. Vaccination coverage and herd immunity as a public common

2. Avoiding the tragedy of the public health common through state action

III. THE CURRENT STRUCTURE OF MANDATORY IMMUNIZATION PROGRAMS AMONG THE STATES

A. The Primary Method of Promoting Immunization Against VPDs

B. Secondary Efforts: Targeting Populations and Disseminating Information

C. The Available Exemptions from Mandatory Immunization Requirements

1. Medical exemptions

2. Religious exemptions

3. Philosophical (personal belief) exemptions

4. Exemptions of convenience

* J.D. Candidate, 2010, Indiana University School of Law - Indianapolis; B.S. in Microbiology, 2000, Indiana University. The author has received vaccinations against anthrax, diphtheria, hepatitis A and B, Haemophilus influenza type b, influenza, measles, meningococcal, mumps, pertussis, polio, rubella, smallpox, tetanus, typhoid, and yellow fever. 
IV. ANALYSIS OF INDIANA'S MANDATORY IMMUNIZATION

PROGRAMS.

A. The Current Structure of Indiana's Mandatory Immunization

Program

1. Primary immunization efforts: efficient targeting of

populations.

2. Secondary immunization efforts: educating the public about VPDs.

3. Enforcement of mandatory immunization requirements in Indiana

4. The mandatory immunization exemptions available to Hoosiers

a. Exemptions in the case of medical contraindication .. 147

b. Exemptions in the case of conflicting religious beliefs 148

B. Recommended Changes to Indiana's Mandatory Immunization

Provisions

1. The current state of vaccination coverage and exemption prevalence

2. Amending the religious exemption statutory provisions.... 150

3. Advocating the taboo: incorporating philosophical exemptions

4. Revisions of mandatory immunization reporting requirements

5. Attempting to internalize the negative externalities of immunization exemption.

\section{INTRODUCTION}

After vaccinations against infectious diseases became available near the end of the nineteenth century, ${ }^{1}$ the United States experienced a remarkable reduction in morbidity and mortality suffered as a result of vaccinepreventable diseases through the widespread use of immunization programs. ${ }^{2}$ These state programs, which involve the compulsory vaccination of school-aged children, ${ }^{3}$ not only eliminated endemic infections domesti-

1. See Robert Langreth, Booster Shot, A New Golden Age of Vaccines Is at Hand, Promising Inoculations Against Malaria, Meningitis, and Much More, ForBES, Nov. 12, 2007, at 79 (discussing Dr. Jenner's discovery of smallpox prevention techniques).

2. See Centers for Disease Control and Prevention, Achievements in Public Health, 1900-1999: Control of Infectious Disease, 48 MORBIDITY \& MORTALITY WKLY REP. 621, 624 (1999) [hereinafter Control of Infectious Disease] (discussing the success of vaccination programs).

3. See Kevin M. Malone \& Alan R. Hinman, Vaccination Mandates: The Public Health Imperative and Individual Rights, in LAW IN PUBLIC HEALTH PRACTICE 338, 355 (Richard A. Goodman ed., 2d ed. 2007). 
cally but also enabled the eradication of some diseases in the United States and throughout the world. ${ }^{4}$

Due in part to the success of these vaccination efforts, many American parents are unfamiliar with the risks posed by these once-prevalent diseases. ${ }^{5}$ Consequently, many parents now resist mandatory vaccinations for their children because they fear the potential adverse effects of vaccinations more than the diseases the vaccines prevent. ${ }^{6}$ As more parents seek to avoid vaccinations through statutory exemptions from mandatory immunization programs, ${ }^{7}$ the public health achievements of these programs - including herd immunity and decreased socio-economic costs - are at risk of collapse. ${ }^{8}$ International travel now reintroduces communicable diseases once eliminated from or greatly curtailed in the United States. ${ }^{9}$ Indiana itself narrowly averted a costly outbreak of measles in the alarmingly recent past. $^{10}$

Section II of this Note will demonstrate that the continuing risks posed by vaccine-preventable diseases compel states to continue enforcing mandatory immunization programs and to minimize exemptions that can lead to a tragedy of the public health common. It will then discuss the opposition to these programs and the increasing number of parents seeking exemptions, focusing on the impact of those decisions by using the "Tragedy of the Commons" 11 as a model for analysis. Section III will introduce the common features of mandatory vaccination programs, including exemption provisions and their constitutional implications. Section IV will discuss the current structure, strengths, and weaknesses of Indiana's mandatory vaccination program. Finally, Section IV will use the analytical framework of the tragedy of the public health common to recommend changes to Indiana's statutory and regulatory provisions.

4. Control of Infectious Disease, supra note 2, at 624.

5. Steve P. Calandrillo, Vanishing Vaccinations: Why Are So Many Americans Opting Out of Vaccinating Their Children?, 37 U. MICH. J.L. REFORM 353, 362 (2004).

6. Ross D. Silverman, No More Kidding Around: Restructuring Non-medical Childhood Immunization Exemptions to Ensure Public Health Protection, 12 ANNALS Health L. 277, 278-79 (2003).

7. See Jennifer Steinhauer, Rising Public Health Risk Seen as More Parents Reject Vaccines, N.Y. TIMES, Mar. 21, 2008, at Al.

8. See, e.g., Bloomberg News, Measles Cases Up As More Shun Shots, Newsday, Jan. 8, 2009, at A30, available at 2009 WL 351178 [hereinafter Measles Cases Up].

9. See Centers for Disease Control and Prevention, Update: Measles - United States, January-July 2008, 57 MORBIDITY \& MORTALITY WKLY REP. 893, 896 (2008) [hereinafter Update: Measles].

10. Amy A. Parker et al., Implications of a 2005 Measles Outbreak in Indiana for Sustained Elimination of Measles in the United States, 355 NEW ENG. J. MED. 447 (2006).

11. Garrett Hardin, The Tragedy of the Commons, 162 SCIENCE 1243 (1968). 


\section{THE PURPOSES FOR AND CONSIDERATIONS OF MANDATORY VACCINATION PROGRAMS}

This section discusses the reasons why states introduced and continue to employ mandatory vaccination programs. It will introduce the reader to concepts of disease prevention as well as to the benefits immunization programs confer. It will also discuss some risks inherent in immunization practices in order to introduce the considerations that legislatures and public health officials must balance when designing vaccination programs.

\section{A. The Health and Socio-economic Impacts of Communicable and Infectious Diseases}

Communicable and other infectious diseases caused thousands of deaths annually in the United States and throughout the world before the advent of concerted public health efforts. ${ }^{12}$ At the turn of the twentieth century, pneumonia, tuberculosis, and diphtheria were the first, second, and tenth leading causes of death respectively in the United States. ${ }^{13}$ In stark contrast, only septicemia and the combination of influenza and pneumonia were within the top ten by $2005 .^{14}$

The benefits of preventing, reducing, or eradicating infectious diseases are not limited to reductions in mortality alone. Even if an infectious disease proves non-fatal in a given case or in most cases of its infection, it may cause significant health consequences. Measles, a systemic infection caused by a virulent paramyxovirus spread by aerosols, provides a startling example. ${ }^{15}$ Although not usually fatal to children in industrialized nations, it creates a spreading rash, moderate to severe fevers, coughs, anorexia, and diarrhea. ${ }^{16}$ Nearly a third of cases result in complications, with severe diarrhea, ear infections, and secondary pneumonia infections being the most common. ${ }^{17}$ Even with medical treatment, some once-common vaccinepreventable diseases can cause blindness, deafness, encephalitis, brain damage, and mental retardation. ${ }^{18}$ Some infectious agents, though preventable

12. See Calandrillo, supra note 5, at 362 .

13. National Center for Health Statistics, Leading Causes of Death, 1900-1998, http://www.cdc.gov/nchs/data/dvs/lead1900_98.pdf, at 67 (last visited Mar. 14, 2009).

14. Hsiang-Ching Kung et al., Deaths: Final Data for 2005, 56 Nat'L Vital Stat. REP., Apr. 24, 2008, at 5, available at http://www.cdc.gov/nchs/data/nvsr/nvsr56/ nvsr56_10.pdf.

15. Centers for Disease Control and Prevention, Epidemiology and Prevention of Vaccine-Preventable Diseases 157 (W. Atkinson et al. eds., 11th ed. 2009) [hereinafter PINK BOOK].

16. Id. at 158 .

17. Id.

18. Centers for Disease Control and Prevention, What Would Happen If We Stopped Vaccinations?, http://www.cdc.gov/vaccines/vac-gen/whatifstop.htm [hereinafter What Would Happen] (last visited Apr. 10, 2010) (describing the impact of Hib-induced meningi- 
through vaccination, are not susceptible to commonly available treatment regimens, especially viruses and highly mutable bacteria. ${ }^{19}$

Infectious diseases have implications beyond the infected individuals - thus truly making them public health problems - because their cumulative secondary effects create significant socio-economic consequences. Infected children often miss school, and their symptoms may require doctor visits or hospitalization. ${ }^{20}$ Some states, including Indiana, require the exclusion of children with communicable illnesses for the duration of their infectious potential, ${ }^{21}$ resulting in missed classes. Parents of young students must provide for their care and may need to take time off of work. ${ }^{22}$ Where parents cannot afford necessary treatments for students, Indiana law requires that public health facilities provide the care, ${ }^{23}$ thus transferring the cost of treatments to treating facilities, public programs, taxpayers, and eventually even insurance premiums. ${ }^{24}$

\section{B. The Rise of Vaccination: The Reduction and Elimination of Endemic Diseases}

Immunity, in the medical context, denotes an individual's ability to eliminate foreign antigens to which the body is exposed while protecting the body's own tissues. ${ }^{25}$ Active immunity may either be conferred by vaccination or acquired from the course of exposure to and recovery from a particular antigen. $^{26}$ But only vaccination enables individuals to develop some level of active immunity without having to experience the disease or risk its potential complications. ${ }^{27}$

Vaccine development began its rapid evolution in the late eighteenth century when Dr. Edward Jenner researched immunizing children against smallpox by intentionally exposing them to blisters of the closely-related cowpox disease. ${ }^{28}$ The concept of conferring immunity by exposure to noninfectious antigens thus became alternatively known as vaccination (due to the name of the cowpox virus, Vaccinia) and immunization (due to the re-

tis, pertussis, and mumps). See also PINK BooK, supra note 15, at 158 (describing measlesassociated encephalitis); $i d$. at 285 (describing varicella-associated encephalitis and aseptic meningitis).

19. See Control of Infectious Disease, supra note 2, at 624 (discussing the emergence of drug resistance in some organisms as underscoring the need for prevention).

20. What Would Happen, supra note 18.

21. See, e.g., IND. CODE ANN. § 20-34-3-9(c) (West 2008) (excluding an infected student until the student is no longer has a communicable disease or poses a transmission risk).

22. What Would Happen, supra note 18.

23. IND. CODE ANN. § 20-34-3-9 (b) (West 2008).

24. See Calandrillo, supra note 5, at 427-28.

25. PINK BoOK, supra note 15 , at 1 .

26. Id. at 3 .

27. Id.

28. Langreth, supra note 1, at 79. 
sulting effect of exposure). ${ }^{29} \mathrm{~A}$ "vaccine-preventable disease" (VPD) is one for which an efficacious method of immunization has been developed and approved; the Centers for Disease Control and Prevention (CDC) currently classify twenty-seven diseases as VPDs. ${ }^{30}$

Immunization practices have led to a remarkable reduction in morbidity and mortality due to VPDs throughout the world. ${ }^{31}$ In the United States, vaccinations against VPDs have resulted in the complete eradication of naturally-occurring infections of smallpox, diphtheria, and paralytic polio, as well as near-total eradication of measles, rubella, congenital rubella, and Haemophilus influenzae. ${ }^{32}$ Accordingly, the CDC proclaimed vaccinations to be one of the ten greatest public health achievements of the previous century. ${ }^{33}$ The results of vaccination programs have been profound, considering the millions of deaths prevented, the reduced morbidity, and the cost savings to families and communities. ${ }^{34}$

Universal childhood vaccination continues to be essential to these successes because of the rampant communication of disease among young children, particularly in school and child care environments. ${ }^{35}$ By focusing on children, immunization programs arrest transmission of infectious diseases by denying them footholds in high-transmission environments. In addition, making certain vaccinations requisites for school attendance "[has] been a key factor in the prevention and control of [VPDs] in the United States." 36 As vaccine advocate Dr. Paul Offit noted, "In the early 1970s, public health officials found that states with vaccine mandates had rates of measles that were $50 \%$ lower than states without mandates."37

Because the prevalence of some diseases can be so dramatically reduced through vaccination, some targeted diseases "[can] be eradicated from all human populations through global cooperation." ${ }^{, 38}$ Indeed, the renowned success of smallpox vaccination led to the global eradication of the Variola virus by $1977 . .^{39}$ This eradication allowed public health authorities

29. This Notes will regard the terms "vaccinate" and "immunize" as synonyms.

30. Centers for Disease Control and Prevention, List of Vaccine-Preventable Diseases, http://www.cdc.gov/vaccines/vpd-vac/vpd-list.htm (last visited Mar. 14, 2009).

31. MALONE \& HINMAN, supra note 3, at 341.

32. PINK BooK, supra note 15 , at G-7.

33. Centers for Disease Control and Prevention, Ten Great Public Health Achievements-United States, 1900-1999, 48 MORBIDITY \& MORTALITY WKLY REP. 241, 243-44 (1999) [hereinafter Ten Great Public Health Achievements].

34. See Calandrillo, supra note 5, at 369.

35. See Derrick Henry, Law on Flu Vaccinations May Be Tested, N.Y. Times, Jan. 4, $2009, \S 14$ (New Jersey), at 2 ("Children are very effective spreaders of infection-prone secretions.").

36. MALONE \& HinMAN, supra note 3, at 355.

37. Paul A. Offit, Editorial, Fatal Exemption, WALL ST. J., Jan. 20-21, 2007, at A10.

38. Control of Infectious Disease, supra note 2, at 624.

39. Centers for Disease Control and Prevention, Laboratory-Acquired Vaccinia Exposures and Infections, 57 MORBIDITY \& MORTALITY WKLY REP. 401 (2008). 
to cease routine vaccination of American children. ${ }^{40}$ The ultimate goals of immunization efforts, therefore, are the eradication of VPDs and the eventual cessation of immunizations against them.

\section{Remaining VPD Risks Compel Continuation of Universal Immunizations}

Although immunization efforts have curtailed VPDs, the majority of VPDs have not been eliminated in the United States, let alone globally. ${ }^{41}$ Even in nations and communities where particular VPDs have been significantly curtailed or eliminated, periodic resurgence of those VPDs occurs. ${ }^{42}$ If states suspend mandatory vaccinations prematurely, the reintroduction of VPDs will likely allow their resurgence to pre-vaccination levels, and prior efforts will have diminished value. ${ }^{43}$

Measles exemplifies the continuing need for universal vaccination. Public health authorities successfully eliminated endemic measles transmission within the United States by the year $2000 .^{44}$ Yet the disease continues to afflict developing nations, ${ }^{45}$ and it reappears even in nations with broad vaccination programs. In the United States, more measles cases were reported in 2008 than in any year since its domestic eradication as a result of international travel, leading the $\mathrm{CDC}$ to note that "[f]or the foreseeable future, measles importations into the United States will continue to occur....,46 Public health officials link the outbreaks to lowered immunization rates. Outbreaks in Great Britain and its territories appear to have resulted from a decline in vaccination coverage. ${ }^{47}$ The CDC noted similar indicators of poor vaccination coverage for outbreaks in the United States. ${ }^{48}$ Measles even resurfaced in Indiana during a 2005 outbreak that occurred among predominantly unvaccinated individuals. ${ }^{49}$

While vaccination programs entail some expenses and inherent risks, they confer multiple essential benefits that strongly outweigh these costs. The primary benefits inure to the vaccinated individual - who is largely

40. Id.

41. See Ten Great Public Health Achievements, supra note 33, at 247 ("Despite the dramatic declines in [VPDs], such diseases persist, particularly in developing countries.").

42. See PINK BooK, supra note 15, at 31 ("The viruses and bacteria that cause [VPDs] ... still exist and can be passed on to unprotected persons or imported from other countries. ...").

43. Id.

44. Update: Measles, supra note 9, at 893.

45. Associated Press, Measles Deaths Down Globally, NewSDAY, Dec. 5, 2008, at A53.

46. Update: Measles, supra note 9 , at 896.

47. See Donald G. McNeil, Jr., Fast-Spreading Outbreak Reveals Lower Immunization Rate in Gibraltar, N.Y. TIMES, Nov. 11, 2008, at D8.

48. Update: Measles, supra note 9, at 893.

49. Parker et al., supra note 10, at 447. 
protected from symptomatic illness - thus increasing the individual's quality of life, reducing medical care costs, and preventing disability or death. ${ }^{50}$ In addition, the comparative costs between vaccination and treatment for the targeted VPD indicate that prevention is far more economical than treatment for a given individual. ${ }^{51}$ The secondary benefits of vaccination programs inure to the community at large. A sufficiently high vaccine coverage rate establishes herd immunity ${ }^{52}$ - a term denoting a community's collective resistance to an infectious disease due to the immunity of a sufficient majority of its members. ${ }^{53}$ Herd immunity generally protects the susceptible persons within a community - both those who have not received a vaccine due to medical contraindication or choice and also those who received the vaccine but did not develop immunity in response to it - by arresting the transmissions necessary to sustain an outbreak. ${ }^{54}$ In turn, herd immunity enables the eradication of targeted VPDs and the eventual discontinuation of vaccination against them. Another secondary benefit of immunization programs is a large-scale reduction in healthcare-related costs. ${ }^{55}$ One expert noted that "we recoup the total cost of [smallpox] eradication in less than two months today." 56 During the 2005 measles outbreak in Indiana, the estimated cost of containing the outbreak was $\$ 167,685$ (almost $\$ 5,000$ per infected patient). ${ }^{57}$ Because most of the costs were borne by public health officials and treating hospitals, ${ }^{58}$ the financial burden to Indiana taxpayers of a statewide epidemic resulting from poor vaccination coverage could easily reach millions of dollars.

Given the continuing global presence of VPDs and the myriad benefits and efficacy of vaccination programs, mandatory childhood vaccination programs must be continued and improved. Such programs help reduce the increasing reintroduction of VPDs and may ultimately enable authorities to suspend vaccination for particular diseases worldwide. ${ }^{59}$

50. Centers for Disease Control and Prevention, General Recommendations on Immunization: Recommendations of the Advisory Committee on Immunization Practices (ACIP), 55 MORBIDITY \& MORTALITY WKLY REP. RR-15, Dec. 1, 2006, at 1 [hereinafter General Recommendations on Immunization].

51. Calandrillo, supra note 5, at 380 ("[VPDs] cost 16 times more in medical-related costs than do the vaccines that prevent those diseases.").

52. General Recommendations on Immunization, supra note 50, at 1.

53. MALONE \& HINMAN, supra note 3, at 340.

54. See Donald G. McNeil, Jr., When Parents Say No to Child Vaccinations, N.Y. TIMES, Nov. 30, 2002, at A1 [hereinafter When Parents Say No].

55. General Recommendations on Immunization, supra note 50, at 1.

56. Mark Roth, After More Than 20 Years, He's Still Awaiting AIDS Vaccine, PITT. Post-GazeTTE, Nov. 24, 2008, at Al (referring to savings based on "present-day treatment costs").

57. Parker et al., supra note 10 , at 452 .

58. Id.

59. Ten Great Public Health Achievements, supra note 33, at 247. 


\section{Increasing Numbers of Parents Resist Childhood Immunizations}

Despite the demonstrated efficacy of vaccines and mandatory vaccination programs, a significant number of parents doubt the value and safety of childhood vaccinations. Throughout the country, individual parents and vocal advocacy groups resist the efforts of state and local governments to ensure universal vaccination. This upward trend, largely based on fears of vaccine side effects, threatens to undermine the local and global benefits of immunization efforts and to prevent the near-term eradication of certain VPDs.

\section{The Inherent Risks of Vaccinations}

While vaccines have been unquestionably beneficial and efficacious, they involve some inherent risks, as do all medical procedures. ${ }^{60}$ Mild local and systemic reactions are common and brief. ${ }^{61}$ In rare cases, however, inoculation causes severe allergic reactions and other serious adverse effects. ${ }^{62}$ It is altogether reasonable for a community to react negatively when a child endures one of the rare severe side effects of vaccination. ${ }^{63}$ Yet the rarity of these proven adverse effects suggests that they are not the primary source of current parental misgivings.

Doubts about vaccine safety and their inherent risks are far from new. As early as 1900, the Indiana Supreme Court addressed parental misgivings about mandatory smallpox vaccination in the case Blue v. Beach. ${ }^{64}$ Frank Blue alleged that "vaccination in all cases produced a loathsome constitutional disease, which poisoned the blood of the patient, and frequently resulted in death, and that vaccination was not a preventative of smallpox." Five years later, the United States Supreme Court addressed opposition to

60. See generally Centers for Disease Control and Prevention, Update: Vaccine Side Effects, Adverse Reactions, Contraindications, and Precautions-Recommendations of the Advisory Committee on Immunization Practices (ACIP), 45 MORBIDITY \& MORTALITY WKLY REP. RR-12, Sept. 6, 1996 [hereinafter Update: Vaccine Side Effects] (describing the common mild and rare severe reactions to commonly-required childhood immunizations).

61. See, e.g., id. at 7 (describing studies of hepatitis $\mathrm{B}$ vaccinations that demonstrated similar reactions to placebo injections); $i d$. at 22-23 (describing the frequency and duration of local and systemic reactions to DPT vaccinations).

62. See, e.g., id. at 19 (discussing the extremely rare occurrence of anaphylaxis for all types of vaccination); Lisa Greene, Two Sides Unable to Bridge Gap, ST. PETERSBURG TIMES, Nov. 24, 2008, at 1A [hereinafter Two Sides Unable to Bridge Gap] (discussing shock or brain inflammation in children receiving DPT).

63. Cf. When Parents Say No, supra note 54, at Al ("Sometimes a community is scared when a child is truly harmed by side effects. ...").

64. Blue v. Beach, 56 N.E. 89 (Ind. 1900).

65. Id. at 91. The court nonetheless upheld the exclusion of Blue's unimmunized son from school as a valid exercise of the regulatory authority delegated to the city by statute. Id. at 97 . 
mandatory vaccination in Jacobson v. Massachusetts, ${ }^{66}$ where Jacobson who had been convicted of failing to abide by a local ordinance requiring smallpox vaccination - sought to prove the injurious or dangerous effects of vaccinations. Jacobson, much like Frank Blue, "offered to prove that vaccination 'quite often' caused serious and permanent injury to the health of the person vaccinated." $"$ The Court rejected his proffer, holding that allowing Jacobson to avoid compelled vaccination based on his fears alone "would practically strip the legislative department of its function to care for the public health and the public safety when endangered by epidemics of disease."

\section{Addressing the risks: using risk balancing to design vaccination pro- grams}

In the century that followed Blue and Jacobson, public health officials have acknowledged and mitigated vaccination risks by using risk-balancing to establish immunization requirements. ${ }^{69}$ Using mechanisms such as the Vaccine Adverse Event Reporting System, public health officials compare the risks of adverse reactions to vaccination with the risks presented by the VPDs at issue and the benefits of universal vaccination, ultimately selecting vaccines for immunization mandates when "[v]accination is safer than accepting the risks for the diseases these vaccines prevent." risks evolve over time (due to the decreased incidence of a VPD or newly documented adverse reactions), public health authorities change vaccination protocols accordingly. ${ }^{71}$ The discontinuation of Rotashield vaccination in 1999 demonstrated officials' vigilance and willingness to amend vaccination protocols as risks are discovered. ${ }^{72}$ This example confirmed that vaccination risks are closely monitored through the Vaccine Adverse Event Reporting System and that changes to vaccine recommendations are made swiftly when even rare serious side effects tip the relative risk balance. ${ }^{73}$

66. Jacobson v. Massachusetts, 197 U.S. 11 (1905).

67. Id. at 36 .

68. Id. at 37

69. See MALONE \& HinMAN, supra note 3 , at 340.

70. Update: Vaccine Side Effects, supra note 60, at 2.

71. See, e.g., MALONE \& HINMAN, supra note 3 , at 340 (discussing the replacement of the more efficacious but more dangerous OPV with the less efficacious but safer IPV when naturally occurring polio infections ceased in the United States).

72. See Centers for Disease Control and Prevention, Withdrawal of Rotavirus Vaccine Recommendation, 48 MORBIDITY \& MORTALITY WKLY REP. 1007 (1999).

73. See Centers for Disease Control and Prevention, Rotavirus Vaccine - Questions and Answers, http://www.cdc.gov/vaccines/vpd-vac/rotavirus/vac-faqs.htm (last visited Apr. 5, 2009). 
3. Misunderstanding the relative risks: are parents afraid of the right threats?

Despite officials' continuing evaluation of relative risks, many parents still fear immunizations and the systems of administration. These individuals likely fail to acknowledge the actual risks of VPDs themselves. As public experience with VPDs wanes due to the efficacy of immunization programs, many individuals may not appreciate the severity of the diseases and instead focus their concerns on "misconceptions of vaccine risks."74 As one scholar described this phenomenon, "[v]accines are becoming a victim of their success - many individuals have never witnessed the debilitating diseases that vaccines protect against, allowing complacency toward immunizations to build."75 Unsurprisingly, when parents witness the impact of a particular VPD, their aversions to vaccination tend to diminish drastically. ${ }^{76}$ Controversies over the alleged risks of vaccination, which even pervade popular culture, ${ }^{77}$ cause many to emphasize "the relative weaknesses and dangers of immunizations, and the systems through which they are administered" instead of the still-present dangers presented by VPDs. ${ }^{78}$ Unfortunately, the growing controversy over perceived vaccination risks engenders increasing distrust of public health institutions. Louise Kuo Habakus, a spokeswoman for the New Jersey Coalition for Vaccination Choice described "a huge trust gap between parents and public health officials."79 The Coalition petitioned New Jersey's legislature in 2008 , "demanding the state abandon all mandatory vaccines, including polio, diphtheria and measles." 80

The rising tide of popular distrust of vaccines has undoubtedly been fueled by allegations that vaccinations are causally linked to the onset of autism. In 1998, a British medical journal published a study that posited a tentative link between symptoms of autism spectrum disorders (ASD) and the administration of the measles-mumps-rubella (MMR) vaccine. ${ }^{81}$ Unfortunately, the professed uncertainty of this widely controverted study did

74. Jennifer S. Rota et al., Processes for Obtaining Nonmedical Exemptions to State Immunization Laws, 91 AM. J. PUB. HEALTH 645, 645 (2001).

75. Calandrillo, supra note 5, at 353.

76. See, e.g., When Parents Say No, supra note 54, at A1 (reporting on one parent's experiences with whooping cough and her resulting support for pertussis vaccination).

77. See, e.g., Lisa Greene, Do They Need the Needle?, ST. PeTERSBURg Times, Nov. 23, 2008, at 1A [hereinafter Do They Need the Needle?] (describing a "spat" between celebrities Amanda Peet and Jenny McCarthy over the merits of childhood vaccination).

78. Silverman, supra note 6, at 278-79.

79. Henry, supra note 35 , at 2.

80. Judy Peet, Shot With Controversy: Despite Protest Against N.J. Flu Vaccine Rule, Deadline Nears, STAR-LEDGER (Newark), Dec. 15, 2008, New Jersey Section, at 11 (reporting that the Coalition obtained more than 10,000 signatures on its petitions). Id.

81. A.J. Wakefield et al., Illeallymphnoid-nodular Hyperpasia, Non-specific Colitis, and Pervasive Developmental Disorder in Children, 351 LANCET 637, 637-41 (1998). 
little to hinder its still-lingering effects. ${ }^{82}$ Though the article has even since been retracted in full, ${ }^{83}$ rates of MMR vaccination in geographical pockets of Great Britain dropped nearly fifteen percent following its original publication, and speculation regarding the causal linkage continues in the United States. ${ }^{84}$ Anecdotal testimony abounds in news media, most with a similar tone: "[T]here have been people who have had these shots and then their child is changed forever . . . . It can't be purely coincidence." 85

Yet in the absence of more evidence, this post hoc ergo propter hoc reasoning demonstrates a classic logical fallacy regarding causation. ${ }^{86}$ The propensity to assume causation based on coincidental timing alone allows anti-vaccine advocates to promote - and undiscriminating listeners to embrace - the specious and possibly non-existent causal link. If a causal relationship does exist between vaccination and the onset of ASD, it seems likely that adverse effect screening efforts would have produced evidence of the relationship, as even the original controversial study posited. ${ }^{87}$ When Rotashield adversely affected only 1 in 10,000 children, the vaccine was pulled from the market. ${ }^{88}$ Dr. Offit reasonably suggests that "if vaccines caused something as common as autism - occurring in up to 1 in 150 children - scientists would have realized it by now." 89 Nonetheless, parents brought the matter before the Omnibus Autism Proceeding (OAP) established by the Vaccine Court, which considered as a matter of law whether the causal linkage existed to award damages for vaccine injuries. ${ }^{90} \mathrm{Al}$ though the OAP special masters determined that the parents failed - rather markedly - to prove causation in each of the first three cases, ${ }^{91}$ the issue will undoubtedly linger as parents continue to pursue their own litigation. ${ }^{92}$

82. See Steinhauer, supra note 7, at A1.

83. Retraction-Ileal-lymphoid-nodular Hyperplasia, Non-specific Colitis, and Pervasive Developmental Disorder in Children, 375 LANCET 445 (2010).

84. See Do They Need the Needle?, supra note 76, at $1 \mathrm{~A}$.

85. Two Sides Unable to Bridge Gap, supra note 61, at $1 \mathrm{~A}$.

86. See Monroe C. BEARDSLEy, Thinking Straight: Principles of REASONING for READERS AND WRITERS 91 (1975) (describing the causation-related post hoc logical fallacy).

87. Wakefield et al., supra note 81 , at 641 .

88. Two Sides Unable to Bridge Gap, supra note 62, at 1A; Centers for Disease Control and Prevention, Withdrawal of Rotavirus Vaccine Recommendation, 48 MORBIDITY \& MORTALITY WKLY REP. 1007 (1999) [hereinafter Withdrawal of Rotavirus Vaccine].

89. Two Sides Unable to Bridge Gap, supra note 62, at 1A.

90. Gordon Shemin, Note, Mercury Rising: The Omnibus Autism Proceeding and What Families Should Know Before Rushing Out of Vaccine Court, 58 AM. U. L. REV. 459, 461 (2008).

91. See, e.g., Cedillo v. Sec'y of Health and Human Serv., No. 98-916V, 2009 WL 331968 , at *1 (Fed. Cl. Feb. 12, 2009) ("The numerous medical studies concerning these issues, performed by medical scientists worldwide, have come down strongly against the petitioners' contentions. Considering all of the evidence, I found that the petitioners have failed to demonstrate [causation].") (emphasis in original).

92. See, e.g., CNN.com, Vaccines Didn't Cause Autism, Court Rules, http://www.cnn.com/2009/HEALTH/02/11/autism.vaccines/index.html (last visited Mar. 14, 2009) (describing one advocacy group's intent to distinguish the rulings from pending cas- 
Regardless of whether this ruling will have future positive effects, many parents currently dread the putative adverse effects of vaccinations. Such fears garner more media attention than the diseases they prevent, which can be attributed to parents' comfortable ignorance of the diseases. ${ }^{93}$ Because such fears persist, parents are increasingly seeking exemptions from mandatory childhood immunization laws in many areas of the country. ${ }^{94}$ Many states have "seen the numbers of schoolchildren with exemptions for vaccines soar[,]" with some communities having exemption rates of up to twenty-five percent. ${ }^{95}$

\section{E. The Harms of Mandatory Vaccination Exemptions: the Problem of the Commons.}

Public health officials and healthcare professionals believe that the decrease in vaccine coverage in populations will lead to a resurgence of VPDs in the United States. ${ }^{96}$ While parents may individually prefer to avoid vaccinations for their children, their choices to do so have ramifications beyond their own families. As Dr. Robert W. Tolan succinctly stated, "If you don't vaccinate your child, you're putting my child at risk." ${ }^{.97}$

In 1968, professor of biology Garret Hardin adapted William Forster Lloyd's analysis of the impact of individually rational choices on the community as a whole to his own analysis of population control in his renowned essay, "The Tragedy of the Commons." ${ }^{.98}$ He posited that if an individual can realize a unit of benefit while simultaneously distributing a concomitant unit of detriment over the community's population, the individual's rational choice would be to take that action. ${ }^{99}$ Yet the collective impact of each individual's rational choice is an unsustainable degradation of the whole: "Ruin is the destination toward which all men rush, each pursuing his own best interest in a society that believes in the freedom of the commons." 100 His analysis provides a useful framework for examining universal vaccination and available exemptions.

\section{Vaccination coverage and herd immunity as a public common}

Attorney Kevin Malone and public health scientist Alan Hinman suggested that "a community free of a communicable disease because of a high

es).

93. See Two Sides Unable to Bridge Gap, supra note 62, at 1A.

94. See Steinhauer, supra note 7, at A1.

95. Shari Rudavsky, Parents' Dilemma: Vaccinate Kids or Not, INDIANAPOLIS STAR, Nov. 29, 2008, at A1.

96. See Measles Cases Up, supra note 8, at A30.

97. Henry, supra note 35 , at 2.

98. Garrett Hardin, The Tragedy of the Commons, 162 SCIENCE 1243 (1968).

99. Id. at 1244 .

100. Id. 
vaccination rate can be viewed as a common."101 For example, if a mother objects to vaccinations and secures an exemption allowing her daughter to attend school unimmunized, she only minimally increases her daughter's risk of infection if the community benefits from herd immunity (the common). Simultaneously, the mother realizes a unit of benefit by avoiding exposing her daughter to the risk of adverse reactions to the required vaccines. ${ }^{102}$ This act of exemption incrementally decreases the vaccination coverage for the community, the maintenance of which is necessary to sustain herd immunity. ${ }^{103}$ Where vaccine coverage is high, this discrete and incremental decrease in coverage (the distributed unit of detriment) is unlikely to subvert the secondary benefits of mandatory vaccination programs, so the individually rational choice for the mother may well be to avoid vaccination. Yet the same choice may be individually rational for all parents in the community. The ultimate result of these aggregated individually rational choices would be the destruction of herd immunity and the elimination of the socio-economic benefits of vaccination programs. The common fails as vaccination coverage levels fall below the thresholds necessary to sustain herd immunity, ${ }^{104}$ leaving the community susceptible to resurgence of VPDs.

\section{Avoiding the tragedy of the public health common through state action}

Pursuant to the inherent authority of its police powers, a state government can intervene to change the individual behaviors that may lead to the collapse of the public health common. Given the factors that lead to the individual decisions to seek exemptions, I contend that an outside actor - in this case the state government or its extensions - can avert the "tragedy of the commons" in the field of VPDs through a combination of three complementary approaches.

First, the state can mandate particular vaccinations to ensure a high level of immunity. ${ }^{105}$ These mandates should comprise the VPDs for which authorities conclude the benefits realized by immunization dramatically outweigh the risks of adverse reactions to the vaccine. Although the government may provide for specialized exceptions from these mandates, these

101. MALONE \& HINMAN, supra note 3, at 339.

102. Id.

103. Id.

104. The necessary thresholds may be easily compromised. For example, epidemiological studies suggest that greater than ninety-five percent vaccination coverage is necessary to prevent measles transmission among schoolchildren in a community. Sonja S. Hutchins et al., Vaccination Levels Associated with Lack of Measles Transmission among PreschoolAged Populations in the United States, 1989-1991, 189 J. OF INFECTIOUS DiSEASES 9 (SUPPLEMENT 1), May 1, 2004, at S108, available at http://www.journals.uchicago.edu/ toc/jid/189/s1.

105. See MALONE \& HinMan, supra note 3, at 339. 
exemptions should be available only where the mandates implicate significant liberty concerns.

Second, the state can educate citizens in order to foster consciousness of the commons. ${ }^{106}$ For the common of herd immunity, deliberate educational efforts should include programs designed to increase awareness of: (1) continuing threats from VPDs; (2) the comparative risks of adverse reactions to vaccines and complications of VPDs; (3) the local, national, and global benefits attained through near-universal vaccination coverage; and (4) the direct impact exemptions have on other members of the community and on global eradication efforts. If successful, these efforts may lead some would-be exemptors to realize the value of the commons, to reevaluate the comparative risks, and to choose vaccination over exemption.

Third, the outside actor may seek to force the internalization of units of detriment that individual community members externalize in reaching their individually rational decisions. ${ }^{107}$ Even if parents have no particular objections to the potential of adverse effects of vaccines, they may choose not to incur the burdens of vaccination because of the cost and time savings realized by securing an exemption instead. State governments should seek to eliminate that perverse financial incentive by imposing on the deciding parent a financial or otherwise significant burden that captures the externalized costs.

\section{THE CURRENT STRUCTURE OF MANDATORY IMMUNIZATION PROGRAMS AMONG THE STATES}

The previous section demonstrated the efficacy of vaccinations and immunization programs, proved the continuing need for mandatory immunization programs, and introduced the concept of herd immunity as a public common. This section examines the current structure of state immunization programs, referring to specific states' provisions as examples, in order to introduce the various means implemented to address risks to public health. I will describe various state vaccination requirements and enforcement mechanisms, as well as the typically available exemptions and their constitutional implications. These descriptions will illustrate the outer limits of states' authorities, highlight successes and failures in VPD management, and provide examples that will guide the subsequent analysis of Indiana's immunization programs.

106. Cf. Hardin, supra note 98, at 1245 ("Education can counteract the natural tendency to do the wrong thing. . . [if] constantly refreshed.").

107. Cf. id. at 1247 (discussing "carefully biased options" to coerce behavior). 


\section{A. The Primary Method of Promoting Immunization Against VPDs}

The authority to act in the interest of public health is vested in the several states. ${ }^{108}$ Courts recognize the duty of state legislatures to protect public health pursuant to their police powers, even where executing that duty involves a marginal infringement on individual choices regarding medical treatment, because individual's choices may endanger the public at large. ${ }^{109}$ Pursuant to this authority, state public health officials focus their finite resources on those populations and causes that can be most readily addressed. In part because children readily transmit communicable diseases and subsequently expose their families to infection, ${ }^{110}$ every state had enacted mandatory vaccination laws for students entering public school by the fall of $1980 .^{111}$ These targeted immunization schemes greatly contributed to the reduction in VPD-associated morbidity and mortality over the previous century. $^{112}$

Some legislatures establish the specific immunization requirements by statute, delineating as a matter of legislative policy which VPDs require state intervention at the legislative level. ${ }^{113}$ Other legislatures delegate the selection of particular VPDs for which to require immunization to public health departments at the state or local levels. ${ }^{114}$ Although the CDC lists twenty-seven diseases as vaccine-preventable, each state requires proof of immunity for only a fraction of those for school entry. ${ }^{115}$ States, with federal financial assistance, ${ }^{116}$ also endeavor to provide free vaccinations to those children whose parents are unable to afford them. The Indiana State Department of Health states rather emphatically on its website: "Clinics that get vaccines from the government are forbidden by law from denying you vaccinations because you can't pay."117

Schools and childcare facilities, in turn, must report their levels of

108. U.S. Const. amend. X. See also Jacobson, 197 U.S. at 37.

109. See B. Jessie Hill, The Constitutional Right to Make Medical Treatment Decisions: A Tale of Two Doctrines, 8 TEX. L. REV. 277, 304 (2008).

110. See Henry, supra note 35 , at 2 .

111. MALONE \& HINMAN, supra note 3 , at 345.

112. Silverman, supra note 6 , at 277.

113. E.g., ConN. Gen. Stat. ANN. § 10-204a (West 2002); Kan. Stat. ANN. § 214.034 (West 2006 \& Supp. 2008).

114. E.g., Mich. Comp. Laws ANN. § 380.1177 (West Supp. 2008); Miss. CodE ANN. § 41-23-37 (West 2007).

115. For a composite listing of the vaccination requirements in individual states and territories, see Centers for Disease Control and Prevention, Childcare and School Immunization Requirements, 3, 2005-2006, available at http:/www.cdc.gov/vaccines/vac-gen/laws/ downloads/izlaws05-06.pdf (last visited Mar. 14, 2009).

116. See MAlone \& HinMan, supra note 3, at 343 (discussing federal assistance through the CDC grant program).

117. Indiana State Department of Health, Frequently Asked Questions, http:// www.in.gov/isdh/17205.htm\#FAQ12 (last visited Mar. 14, 2009). 
vaccination compliance to state authorities, ${ }^{118}$ which allows public health officials to track coverage and focus enforcement efforts. Many states combine the school-entry vaccination requirements with mandatory school attendance policies to create enforceable protocols that compel parents to comply with immunization or documented exemption requirements. ${ }^{119}$ In some states, legislators have delegated statutory authority to agencies to enforce mandatory immunization programs against school officials who fail to meet statutory or regulatory requirements. ${ }^{120}$ Ultimately, the efficacy of school-entry requirements depends on the cooperation of state and local entities to execute the program. ${ }^{121}$ No state's mandatory vaccination program is a "fire-and-forget" system that can be ignored once implemented.

\section{B. Secondary Efforts: Targeting Populations and Disseminating Information}

State agencies also devote resources to immunization efforts that school attendance requirements alone could not adequately address. Immunization mandates for students alone might leave populations either susceptible to infection or capable of VPD transmission at social institutions where the impacts may be most critical. To avoid this problem, states may require members of especially susceptible populations, such as hospitalized patients, to prove immunity or undergo vaccination as adults - especially for those nosocomial infections most likely to be transmitted and sustained in hospital settings. ${ }^{122}$ This requirement helps prevent the incubation and transmission of life-threatening illnesses among the community's most vulnerable members.

Because state immunization requirements for public-school entry focus on only a small number of the diseases for which vaccines are available, these programs leave decisions regarding the remaining available vaccines to parents of minor children and adults facing immunization decisions. Through annually published recommended immunizations schedules, the CDC recommends some vaccinations for general use that are typically not required for public school entry. ${ }^{123}$ Some states incorporate this recom-

118. E.g., NeB. REV. STAT. § 71-1913.01(2) (2003).

119. See, e.g., Davis v. Maryland, 451 A.2d 107 (Md. 1982) (upholding parent's conviction on truancy charges when his child was excluded due to a lack of mandatory immunizations).

120. E.g., IND. CODE ANN. § 20-34-4-5 (West 2008).

121. See Silverman, supra note 6 , at 277-78.

122. See, e.g., IND. CODE ANN. § 16-28-14-3 (West 2008) (requiring the vaccination of all health facility patients against influenza and pneumococcal disease).

123. For the most recently published guidelines, see Centers for Disease Control and Prevention, Recommended Immunization Schedules for Persons Aged 0-18 Years-United States, 2008, 57 MORBIDITY \& MORTALITY WKLY REP. 1 (2008), at Q1, available at http:// www.cdc.gov/mmwr/PDF/wk/mm5701.pdf. 
mended schedule into state information dissemination efforts to encourage parents to comply with available, efficacious vaccination options. ${ }^{124}$ Even where immunization for a particular disease is not mandatory for school attendance, states may require that parents are at least informed of the benefits and availability of a particular vaccine. ${ }^{125}$ Following a period of lax school-entry requirement enforcement in the Atlanta area, the Fulton County Department of Health and Wellness nursing director demonstrated a fundamental understanding of the importance of education in encouraging compliance, explaining that the jurisdiction "will launch programs to educate principals, superintendents, day care operators and parents about the importance of vaccinations." 126 Educational programs serve to maximize voluntary vaccination while demonstrating the conscious decisions of state authorities to limit mandatory compliance to those VPDs that pose the most egregious risks to the community.

\section{The Available Exemptions from Mandatory Immunization Requirements}

While state governments have the authority under the police power to act contrary to desires of particular individuals in the interest of public health, infringements of personal autonomy are strongly disfavored in our national culture. In the 1891 opinion of the United States Supreme Court in Union Pacific Railroad Company v. Botsford, ${ }^{127}$ Justice Gray wrote, "No right is held more sacred, or is more carefully guarded by the common law, than the right of every individual to the possession and control of his own person, free from all restraint or interference of others, unless by clear and unquestionable authority of law." ${ }^{28}$ Although state legislation and a Federal Rule of Civil Procedure superseded some portions of Botsford, ${ }^{129}$ its articulation of the primacy of autonomy in the United States survives. The Court revisited autonomy infringement in a medical context in Jacobson, closing its opinion by noting that a legislature or board with delegated authority could potentially impose requirements "so arbitrary and oppressive in particular cases, as to justify the inference of the courts to prevent wrong and oppression."130 The Court held that mandatory immunization against smallpox would be a valid exercise of the state's police power unless for a

124. E.g., N.Y. COMP. CoDES R. \& REGS. tit. 10, § 66-1.1 (2008).

125. E.g., IND. CODE ANN. $§ 20-34-4-5.5$ (West 2008) (requiring confirmation from parents of female students entering sixth grade that they received HPV information from the school).

126. Alison Young, Watching Out For Your Safety and Pocketbook, ATLANTA J.ConsT., Nov. 23, 2008, at D1.

127. Union Pac. R. Co. v. Botsford, 141 U.S. 250 (1891).

128. Id. at 251 .

129. See FED. R. Crv. P. 35 (authorizing courts to order compulsory examinations for "a party whose mental or physical condition . . . is in controversy. ...").

130. Jacobson, 197 U.S. at 38. 
particular individual it could "be shown with reasonable certainty that he is not at the time a fit subject of vaccination, or that vaccination, by reason of his then condition, would seriously impair his health, or probably cause death." 131

One may reasonably assume that the Court's willingness to defer to states' legislative judgment regarding infringement of autonomy directly relates to the legitimacy, and in some cases urgency, of the public health purpose addressed. ${ }^{132}$ The public support for such actions may similarly wax and wane with the immediacy of a known threat. Perhaps recognizing that addressing the threats posed by VPDs may require only near-universal immunization coverage, each state and territory allows citizens to secure certain exemptions from vaccination mandates under at least some circumstances, ${ }^{133}$ thus preserving individual autonomy where practicable. Specific available exemptions vary in each state and territory, but they are generally classified as medical, religious, or philosophical. ${ }^{134}$ In certain jurisdictions with weakly designed programs, a fourth de facto category emerges: an "exemption of convenience.",

\section{Medical exemptions}

All jurisdictions provide exemptions from mandatory immunization schedules to individuals for whom vaccinations are medically contraindicated. $^{136}$ Vaccine inoculation is medically contraindicated where, in the judgment of a health care professional, the vaccine would be positively detrimental to an individual's health beyond minor anticipated adverse effects. ${ }^{137}$ Compelled immunization in such a case would be, as the Jacobson Court noted, "cruel and inhuman in the last degree[,]"138 and therefore almost certainly unconstitutional.

In order to qualify for a medical exemption, most states only require parents to present documentation from a physician attesting to the student's medical ineligibility for vaccination. ${ }^{139}$ Some states, however, actually scrutinize the applications and reject some they regard as specious. For example, the chief physician for New York City's Board of Education, Dr.

131. Id. at 39.

132. See id. at 27 ("Upon the principle of self-defense, of paramount necessity, a community has the right to protect itself against an epidemic of disease which threatens the safety of its members.").

133. See Calandrillo, supra note 5 , at 413 .

134. Id. at 412 .

135. Id. at 413.

136. MALONE \& HINMAN, supra note 3 , at 348 .

137. PINK BOOK, supra note 15 , at 17.

138. Jacobson, 197 U.S. at 39.

139. Daniel A. Salmon et al., Health Consequences of Religious and Philosophical Exemptions From Immunization Laws: Individual and Societal Risk of Measles, 281 JAMA 47, 48 (1999). 
Terry Marx, explained that city officials reject "bogus" applications "if they're based on quackery." 140

The availability and approval of medical exemptions lacks the controversy inherent with other types of vaccination exemptions. The absolute need for the availability of medical exemption seems clear from Supreme Court jurisprudence, ${ }^{141}$ as well as from common sense. The only visible battles regarding medical exemptions occur over the propriety of reviewing a medical exemption application within a state's specific statutory or regulatory provisions. ${ }^{142}$ Yet I contend that two concerns are conceivable: (1) parents may secure a willing physician's recommendation for exemption without a reasonable or even plausible need for one; and (2) once-present contraindications may recede over time without the granted exemption expiring.

\section{Religious exemptions}

A second type of exemption from mandatory immunization programs allows those who assert conflicting religious beliefs to avoid vaccination as a requisite for school attendance, childcare, or hospitalization. Religious exemptions are currently available to citizens in forty-eight states. ${ }^{143} \mathrm{Al}-$ though the language of the relevant statutory provisions and their requirements varied, three elements commonly appeared. First, some states attempted to limit the number of questionable religious exemptions by requiring the exemptor to be affiliated with a recognized, organized religion; this once-common requirement now appears to remain in effect in only two states, Iowa and Nebraska. ${ }^{144}$ A second common element requires the applicant to aver to sincerely held religious convictions or beliefs. ${ }^{145}$ This element facially confronts the practice of applicants seeking religious exemptions without truly adhering to a faith system that would be in any way compromised by vaccination. ${ }^{146}$ A third element occasionally included by legislatures requires applicants to allege that the tenets of their faith specifi-

140. Donald G. McNeil, Jr., Worship Optional: Joining a Church to Avoid Vaccines, N.Y. TIMES, Jan. 14, 2003, at F1 [hereinafter Worship Optional].

141. See Jacobson, 197 U.S. at 39.

142. See, e.g., Jones v. Wyoming St. Dep't of Health, 18 P.3d 1189 (Wyo. 2001) (holding that the Department's denial of a medical exemption due to the applicant's failure to substantiate his claim of a history of reactions to vaccines was not permitted under state law, which required only that the applicant apply and did not provide for discretionary review).

143. Rota et al., supra note 74 , at 645 . (2006).

144. Iowa CODE ANN. § 139A.8(4)(b) (West Supp. 2008); Neb. Rev. Stat. § 71-221(2)

145. See, e.g., N.Y. Public Health LaW § 2164(9) (McKinney 2002); Del. Code ANN. tit. 14, $\$ 131$ (Supp. 2008) (providing the affidavit format necessary for exemption).

146. See generally Worship Optional, supra note 140, at F1 (describing the author's personal experience with a religion often joined by individuals merely seeking exemptions). 
cally conflict with immunization. ${ }^{147}$ This third element, carefully drafted, could serve two laudable purposes. Requiring applicants to specify the conflicts, rather than alleging them generally, could allow reviewers to evaluate the reasonableness of the applications and thus prevent applicants from seeking exemption with absolute ease. It would also promote reflection by the applicant on both the nature of vaccination and the tenets of his or her faith, perhaps leading some to determine that exemption is not necessary to comport with their particular religious beliefs.

Unlike medical exemptions, religious exemptions have led to an extensive body of litigation. Despite constitutional guarantees of religious freedom at the federal ${ }^{148}$ and state ${ }^{149}$ levels, the United States Supreme Court has acknowledged that, pursuant to their police powers, states may infringe on aspects of religious observation under certain conditions: "[A]ctivities of individuals, even when religiously based, are often subject to regulation by the States in the exercise of their undoubted power to promote the health, safety, and general welfare ...."150 But when developing mandatory immunization programs, legislators and administrators must carefully consider both the Free Exercise and the Establishment Clauses of the First Amendment to the United States Constitution. ${ }^{151}$ Substantial debate continues over whether a free exercise right mandates that states provide for religious exemption. ${ }^{152}$ Yet even the seemingly cautious course of allowing for religious exemptions presents some constitutional concern, because the Establishment Clause might prohibit a state from granting religious exemptions due to the perceived recognition and promotion of religion by the state. ${ }^{153}$ Where the majority of individuals in a state must assume the burdens of vaccination costs and potential adverse effects in order to promote public health while a minority escapes these burdens due to professed religious beliefs, the state may simultaneously violate the Equal Protection Clause of the Fourteenth Amendment and the Establishment Clause of the First Amendment by recognizing religion as a justifica-

147. See, e.g., MONT. CODE ANN. § 20-5-405(1) (2007) (including a warning of penalties for false swearing); GA. CODE ANN. $\S 20-2-771($ e) (West 2007) (requiring specific statement that the exemptor's religious tenets conflict with the immunization practice).

148. U.S. CONST. amend. I.

149. E.g., IND. CoNST. art. I, $\S 3$ ("No law shall, in any case whatever, control the free exercise and enjoyment of religious opinions, or interfere with the rights of conscience.").

150. Wisconsin v. Yoder, 406 U.S. 205, 220 (1972).

151. The First Amendment provides that "Congress shall make no law respecting an establishment of religion, or prohibiting the free exercise thereof. ..." U.S. CONST. amend. I. The operation of the Due Process Clause of the Fourteenth Amendment, U.S. ConST. amend. XIV, $\S 1$, cl. 3, constrains state actions in accordance with the Establishment and Free Exercise Clauses. Cantwell v. Connecticut, 310 U.S. 296, 303-04 (1940).

152. See MALONE \& HINMAN, supra note 3, at 349-50 (surveying the progress of Free Exercise Clause jurisprudence in the context of compulsory immunization).

153. See Torasco v. Watkins, 367 U.S. 488, 495 (1961) (holding that a state government cannot "constitutionally pass laws or impose requirements which aid all religions as against non-believers. ..."). 
tion for differential treatment. ${ }^{154}$

Unfortunately, the constitutional jurisprudence resulting from challenges under the Free Exercise and Establishment clauses is convoluted at best, leaving state legislatures with the difficult task of navigating troubled waters with little guidance. In Lemon v. Kurtzman, ${ }^{155}$ the U.S. Supreme Court considered whether Pennsylvania and Rhode Island violated the Establishment Clause by providing financial support to parochial schools and teachers. Calling upon the "cumulative criteria developed by the Court" in its history of cases, Chief Justice Burger summarized a three-part test for determining if a state policy violates the Establishment Clause: "First, the statute must have a secular legislative purpose; second, its principal or primary effect must be one that neither advances nor inhibits religion; finally, the statute must not foster an excessive government entanglement with religion."156

Applying this test to a state's provision of religious exemptions shows a potential conflict with the second and third prongs. While a clear secular purpose of the provision may be the constitutional preservation of mandatory immunization programs by allowing for free exercise of religion, the primary effect of the exemption provision might be to advance religion by creating benefits (through risk- and cost-avoidance) for those of certain faiths. In addition, the threshold for "excessive government entanglement with religion" 157 under the third prong may be lower than one would initially perceive. ${ }^{158}$ The Lemon Court admitted that "the line of separation . . . is a blurred, indistinct, and variable barrier depending on all the circumstances of a particular relationship ...."159 It ultimately based its finding of an impermissible degree of entanglement under the circumstances in large part on the inevitable political involvement of religious advocates and secular opponents:

154. Similar reasoning led the Mississippi Supreme Court to strike down the Mississippi provision allowing religious exemptions from school-attendance vaccination requirements. See Brown v. Stone, 378 So.2d 218, 223 (Miss. 1979) ("[W]e hold that the provision providing an exception from the operation of the statute because of religious belief is in violation of the Fourteenth Amendment to the United States Constitution and therefore is void."), cert. denied, 449 U.S. 887 (1980). Accord Lemon v. Kurtzman, 403 U.S. 602, 612 (1971) ("A given law might not establish a state religion but nevertheless be one "respecting" that end in the sense of being a step that could lead to such establishment and hence offend the First Amendment.").

155. Lemon v. Kurtzman, 403 U.S. 602 (1971).

156. Lemon, 403 U.S. at $612-13$ (internal citations and punctuation omitted).

157. Walz v. Tax Comm'n, 397 U.S. 664, 674 (1970).

158. In Walz, the Court noted that "[t]he test is inescapably one of degree[,]" 397 U.S. at 674, and held that New York's real estate tax exemption for church properties was constitutional. Id. at 680. The Lemon Court characterized the Walz holding as "tend[ing] to confine rather than enlarge the area of permissible state involvement with religious institutions by calling for close scrutiny of the degree of entanglement involved in the relationship." 403 U.S. at 614 .

159. Lemon, 403 U.S. at 614. 
Partisans of parochial schools ... will inevitably champion this cause and promote political action to achieve their goals. Those who oppose state aid, whether for constitutional, religious, or fiscal reasons, will inevitably respond and employ all of the usual political campaign techniques to prevail. Candidates will be forced to declare and voters to choose ...

Ordinarily political debate and division, however vigorous or even partisan, are normal and healthy manifestations of our democratic system of government, but political division along religious lines was one of the principal evils against which the First Amendment was intended to protect. ${ }^{160}$

In the end, no clear standards exist that either mandate or prohibit the provision of religious exemptions from mandatory immunization practices. Previous state decisions, such as the Mississippi decision Brown v. Stone, ${ }^{161}$ suggest that states have no constitutional mandate to provide religious exemptions, but the Supreme Court has yet to directly address whether they are permissible where offered. ${ }^{162}$

Dissenting from the majority in a case arising in Indiana, Justice Rehnquist characterized the apparently conflicting mandates of the Establishment and Free Exercise Clauses: "[A] cause of the tension is overly expansive interpretation of both Clauses .... [T] [ Court has constantly narrowed the channel between the Scylla and Charybdis through which any state or federal action must pass in order to survive constitutional scrutiny." "163 One trend is at least clear; where plaintiffs have challenged statutory exemptions requiring that the individual's claimed religion be staterecognized, courts have held the provisions unconstitutional as violative of the Establishment Clause. ${ }^{164}$ Beyond the infirmity of that element, what

160. Lemon, 403 U.S. at 622.

161. Brown v. Stone, 378 So.2d 218 (Miss. 1979) (holding that a religious exemption from compulsory vaccination would discriminate against the majority of students whose parents do not seek exemptions by exposing them to health risks), cert. denied, 449 U.S. 887 (1980).

162. Silverman, supra note 6, at 281.

163. Thomas v. Review Bd. of the Ind. Employment Div., 450 U.S. 707, 721 (1984) (Rehnquist, J., dissenting) (emphasis in original).

164. See, e.g., Sherr v. Northport-E. Northport Union Free Sch. Dist., 672 F. Supp. 81, 89 (E.D.N.Y. 1987) ("[L]imitation of a religious exemption from vaccination to those who are members of recognized religious organizations is blatantly violative of that First Amendment guarantee.") (emphasis added). 
little guidance these precedents afford may suggest that religious exemptions from immunization mandates are constitutionally suspect. State laws requiring averment of sincere religious beliefs or descriptions of conflicting tenets are facially neutral, but any threshold for conflict or sincerity below which exemption applications can be denied may lack justiciable standards for administrators. ${ }^{165}$ If state or local administrators cannot constitutionally question even a feigned shibboleth, then the sincere belief and conflicting tenets elements lack much of their intended substance. ${ }^{166}$ To illustrate the point, consider Dr. Walter P. Schilling, a New Jersey chiropractor who runs the Congregation of Universal Wisdom, who touts his " 5,520 members, mostly families wanting to avoid vaccination, in 28 states."167 Although the question of sincerity could conceivably be evaluated based on the applicant's conduct, ${ }^{168}$ the administrative burden of such evaluation in each case would be immense, if not prohibitive.

The Lemon Court noted that the "political divisiveness related to religious belief and practice is aggravated" where demands are likely to grow over time. ${ }^{169}$ Because parents increasingly fear vaccines and oppose forced immunization, the number of religious exemptions sought is likely to increase, thus forcing the issue into the political arena - especially in states where the only means for parents to avoid vaccinations is a religious exemption. ${ }^{170}$ So while the applicable test for constitutionality of stateprovided religious exemptions from mandatory immunization protocols is uncertain, ${ }^{171}$ it appears that any statute providing religiously-based exemptions is not immune to constitutional attacks. Yet, because there is no sufficient alternative to mandatory vaccination to combat and eradicate VPDs, an unenviable task remains for legislators. They must either (1) develop a scheme that recognizes free exercise of religion without running afoul of establishment constraints, or (2) determine as a matter of policy that, under

165. See, e.g., Silverman, supra note 6, at 287-88 (discussing a holding of the U.S. District Court of the Northern District of New York that, despite inconsistencies in behavior and testimony and a lack of knowledge of the church's organization and tenets, a would-be exemptor still showed the requisite sincerity necessary to be exempted from mandatory immunizations).

166. See id. at 288 (discussing the power of "magic words").

167. Worship Optional, supra note 140 , at F1.

168. See, e.g., id. (quoting the chief physician of New York City's Board of Education saying, "If someone were really and truly part of this church and upheld its beliefs, that would pass the test. But only if somebody really obeyed this. That means they wouldn't treat their kid for asthma, wouldn't take their kid for an appendectomy.").

169. Lemon, 403 U.S. at 623.

170. See Worship Optional, supra note 140, at F1 ("Parents opposing vaccination often apply for religious exemptions when they cannot get philosophical or medical ones....").

171. See MAlONE \& HinMan, supra note 3, at 349-50 (discussing the judicial reduction of strict scrutiny in the free exercise context, Congress's subsequent passage of the Religious Freedom Restoration Act (RFRA) of 1993, and the U.S. Supreme Court's subsequent finding that RFRA was unconstitutional). 
the Supreme Court's reasoning of Wisconsin v. Yoder, ${ }^{172}$ the public health goals sought justify the abandonment of a religious exemption altogether.

\section{Philosophical (personal belief) exemptions}

The third de jure exemption from mandatory immunization allows those with philosophical or personal beliefs that conflict with vaccination to avoid inoculation for their children. Such philosophical exemptions are currently available in twenty states, ${ }^{173}$ though various accountings of states allowing such exemptions may differ because some statutes and regulations allow for personal belief exemptions without necessarily delineating between religious and philosophical beliefs. ${ }^{174}$ In January of 2008, New Jersey became the most recent state to consider adding a philosophical exemption when Assemblywoman Charlotte Vandervalk introduced a bill proposing conscientious exemptions from mandatory immunization. ${ }^{175}$

In states without exemptions for personally-held but not religious beliefs, available religious exemptions may result in de facto philosophical belief exemptions. ${ }^{176}$ This situation does not obtain if religious exemptions are scrutinized - that is, if exemptions are denied because the applicant's stated reasons for seeking exemption do not arise from religious teachings or belief. ${ }^{177}$ But any delineation between religion and philosophy is unclear, ${ }^{178}$ leaving administrators in difficult positions when determining whether to grant a religious exemption or deny the application as philosophically-based. If religious exemptions are not policed - that is, if they are granted without review for sincerity and source of opposition to vaccination - then exemptors may file under religious exemption provisions even without genuine religious objections. ${ }^{179}$ Some state officials in Indiana suspect

172. Yoder, 406 U.S. at 215 ("[O]nly those interests of the highest order and those not otherwise served can overbalance legitimate claims to the free exercise of religion.").

173. National Conference of State Legislatures, School Vaccination Exemption Laws, http://www.ncsl.org/programs/health/SchoolExempLawsChart.htm (last visited Mar. 15, 2009).

174. E.g., CAL. Health \& SafeTy Code $\S 120365$ (West 2007) (requiring "a letter or affidavit stating that the immunization is contrary to his or her beliefs" without reference to the religious or philosophical source thereof).

175. A.B. 260, 213th Leg.,1 st Ann. Sess. (N.J. 2008).

176. See Worship Optional, supra note 140 , at $\mathrm{F} 1$.

177. See, e.g., Farina v. Bd. of Educ. of City of New York, 116 F. Supp. 2d 503, 505 (S.D.N.Y. 2000) (denying mother's exemption request because the stipulated source of her objection was secular and not religious: "Oh, come on, I'm .Catholic. . . It's really not a religious belief, it's a personal belief.").

178. See Malone \& HINMAN, supra note 3, at 352-53 ("Decisions by the U.S. Supreme Court ... . indicate that a bright line may not always exist between the religious and the philosophic and that at least some amount of philosophic opposition to vaccination may rise to the level of being religious. ...").

179. See Calandrillo, supra note 5, at 415-16 (arguing that officials should be able to inquire into sincerity of religious objections to prevent the erosion of the intent of the ex- 
that a number of parents are exploiting this approach, regardless of religious beliefs. ${ }^{180}$ Ultimately, the unfettered availability of a de jure or a de facto philosophical objection renders a mandatory immunization program a voluntary program. Absent significant administrative hurdles in applying for an exemption from the designated official, nothing prevents the parents of every child from seeking and securing exemptions. Only a personal belief in the efficacy and value of vaccinations then serves to compel parents to comply with the immunization requirements.

Unfettered availability of personally-held belief and philosophical exemptions could dramatically and dangerously expand the number of individuals who go unimmunized. In 1998, in states where such exemptions were available, "parents [were] taking advantage of such exemptions with growing regularity; and in states offering both exemptions, the number of philosophical exemptions far exceed[ed] the number of religious and medical exemptions." "181 Such an increase in exemptions can render communities with even a marginally increased proportion of unvaccinated individuals susceptible to VPD outbreaks. ${ }^{182}$ More recent reports also show an increase in claimed philosophical exemptions, particularly among geographically-clustered groups. ${ }^{183}$ Geographic clustering of exempt populations is of particular concern, because the pockets lack the herd immunity necessary to protect those who cannot be vaccinated and those with weakened immune systems within the community. ${ }^{184}$ To date, state and national reports have aggregated vaccination coverage data at the state level, potentially preventing the detection of geographically-clustered groups that tend to increase the risk of VPD outbreaks. ${ }^{185}$

\section{Exemptions of convenience}

Lax enforcement or ambiguous language in statutes and regulations can lead to the creation of a de facto fourth category of mandatory immunization program exemptions: exemptions of convenience. ${ }^{186}$ Parents, for

emptions). See also Silverman, supra note 6 , at 285 ("[T] he lack of statutory authority . . . to challenge claims based on religious beliefs, or the relaxed enforcement of existing rules, allows virtually any applicant in such states to gain exemption.").

180. Rudavsky, supra note 95, at A1.

181. Silverman, supra note 6, at 284 (citing Daniel R. Feikin et al., Individual and Community Risks of Measles and Pertussis Associated with Personal Exemptions to Immunization, 284 JAMA 3145, 3147 (2000)).

182. See Update: Measles, supra note 9, at 894 (reporting non-immunized patient data).

183. See Chris Joyner, Vaccination Schedules: Safety Concerns Surface on Both Sides of Debate, USA TODAY, Oct. 22, 2008, § B (Life), at 11.

184. See When Parents Say No to Child Vaccinations, supra note 53, at A1.

185. Centers for Disease Control and Prevention, National, State, and Local Area Vaccination Coverage Among Children Aged 19-35 Months-United States, 2007, 57 MORBIDITY \& MORTALITY WKLY REP. 961 (2008).

186. See When Parents Say No, supra note 54, at A1 (noting that in states such as California it may be easier to exempt than comply with vaccination schedules). 
example, may claim exemptions for their children simply "because it was easier to do so than to go to the effort of finding [their child's] immunization record." 187 One 2001 study noted that "[a]n inverse relationship was observed between the complexity of requirements and the proportion of children claiming exemptions." 188 As Daniel A. Salmon, a researcher at the Johns Hopkins School of Public Health, succinctly stated, "People take the path of least resistance ...."189 These statements underscore the need for rigorous screening procedures to limit exemption availability to. those for whom states designed the exemptions.

Exemptions of convenience have a direct and deleterious impact on herd immunity and VPD resistance within a community. Commenting on a 2006 study comparing VPD incidence and exemption prevalence published in the Journal of the American Medical Association, Dr. Offit noted that "states with easy-to-obtain philosophical exemptions had twice as many children suffering from pertussis ... than states with hard-to-obtain philosophical exemptions." 190 States may justifiably decide to make nonmedical exemptions available to their citizens in the interest of personal autonomy, but no reasonable arguments in favor of allowing parents to avoid vaccinating their children for convenience alone can be sustained. While detailed scrutiny of applications may be cost prohibitive, the complexity of the application process alone may offer some level of public health protection. ${ }^{191}$ More complex processes should not deter a parent with sincerely-held beliefs opposed to vaccination, and the complexity of a process that nonetheless yields exemptions for those with sincere beliefs cannot be said to significantly infringe upon autonomy. States should therefore design their processes for obtaining exemptions to "properly reflect the importance that society has accorded immunization through its laws."192

\section{ANALYSIS OF INDIANA'S MANDATORY IMMUNIZATION PROGRAMS}

The foregoing sections provide the necessary background and analytical framework for a principled examination of Indiana's mandatory immunization program. This section first explores the current structure of Indiana's program, comparing it to those of other states in order to assess its strengths and weaknesses. The remainder then recommends changes to sta-

187. Calandrillo, supra note 5, at 418 (quoting Alan R. Hinman et al., Childhood Immunization: Laws that Work, 30 J.L. MED. \& ETHICs 122, 125 (2002)).

188. Rota et al., supra note 74 , at 647.

189. When Parents Say No, supra note 54, at A1.

190. Offit, supra note 37, at A10.

191. See Rota et al., supra note 74, at 647 (noting that none of the states with the most complex category of application requirements had a high degree of exemption).

192. Id. at 648 . 
tutory and regulatory provisions that would increase the program's efficacy and constitutionality.

\section{A. The Current Structure of Indiana's Mandatory Immunization Program}

Indiana's mandatory immunization provisions share common characteristics with the majority of other states. I will first examine Indiana's primary and secondary methods of ensuring a high vaccination coverage rate. Then I will discuss its available exemptions. At each point, I will assess the strengths and weaknesses of the state's provisions.

\section{Primary immunization efforts: efficient targeting of populations}

Recall that the first means for avoiding the tragedy of the public health commons is for a state to intervene and compel a particular behavior. ${ }^{193}$ Indiana employs this method by mandating immunization against some VPDs, focusing its vaccination efforts on school-aged children. This approach maximizes efficiency for state and local health officials by targeting a key population in the transmission of VPDs. The cohort of children entering school each year can be easily identified, because Indiana law requires the attendance of all children in specific age ranges, ${ }^{194}$ as well as the maintenance of attendance records. ${ }^{195}$ Targeting these identifiable populations obviously increases aggregate vaccination coverage as children mature and new identifiable populations enroll. In contrast to many states that base mandatory immunization programs strictly on school attendance, Indiana statutorily requires every child residing in Indiana to be immunized against diphtheria, pertussis, tetanus, measles, rubella, polio, and mumps. ${ }^{196}$ This provision applies to children other than those entering public schools - such as those who will be home-schooled - thus laudably avoiding underinclusion that could lead to unimmunized clusters of children within particular communities.

Indiana's statutory provisions confer significant authority on an administrative agency to develop and execute the mandatory vaccination program. One key provision authorizes the state department of health to "expand or otherwise modify" the required immunizations as "medical information becomes available that would warrant the expansion or modification in the interest of public health." ${ }^{197}$ This provision allows for the administrative addition of a vaccination requirement militated by public health concerns without the necessity of legislation. The provision may

193. See discussion supra Part II.E.2.

194. IND. CODE ANN. $§ ~ 20-33-2-6$ (West 2008).

195. IND. CoDE ANN. $\S 20-33-2-20$ (West Supp. 2008).

196. IND. CoDE ANN. § 20-34-4-2(a) (West 2008).

197. IND. CoDE ANN. § 20-34-4-2(c) (West 2008). 
also allow for the discontinuation of a vaccination requirement in the event of domestic eradication, although the "otherwise modify" language has not yet been construed to either obviate or require the need for legislative amendment. Rather than specifying how or when the immunizations are administered, the statute also delegates the authority for developing these rules to the state department of health. ${ }^{198}$ The agency therefore has the authority to adapt immunization protocols in response to changing policy considerations, such as updated recommended vaccination schedules. This distribution of power also shields decision-makers from the direct political pressures often applied to elected officials, thus reducing the likelihood of a court finding excessive entanglement between legislators and religious advocates. ${ }^{199}$

Indiana code further mandates that schools notify parents of immunization requirements upon school enrollment. ${ }^{200}$ If a parent does not provide a written statement attesting to the student's immunizations, accompanied by certificates or documents provided by the physician administering the vaccines,${ }^{201}$ then the student will not be allowed to attend school beyond the first day without a waiver. ${ }^{202}$ The allowed waivers provide for extenuating circumstances and should serve to eliminate typical inconveniences from being realistic barriers to compliance. ${ }^{203}$

In order to reach the maximum number of citizens who are particularly susceptible to VPD transmission, Indiana also statutorily requires immunizations for children attending state-licensed child care facilities and young adults attending state colleges and universities in Indiana. A childcare facility licensed in Indiana must ensure that each child cared for in the facility has received age-appropriate immunizations. ${ }^{204}$ These provisions allow public health officials to identify and reach specific populations of children before they are subject to school-entry requirements but while they are nonetheless highly susceptible to infection and prone to transmission to other children and their families. At the other end of the youth spectrum, Indiana law ensures that students - both those from other states and also those not already reached by the state's school-entry requirements - matriculating at state higher education institutions are immunized against diphtheria, tetanus, measles, mumps and rubella. ${ }^{205}$ A separate provision requires a certificate of immunization against meningococcal disease for incoming

198. IND. CODE ANN. § 20-34-4-2(d) (West 2008).

199. See supra text accompanying notes $155-60$.

200. IND. CODE ANN. § 20-34-4-3(a) (West 2008).

201. See IND. CODE ANN. $\S 20-34-4-4$ (b) (West 2008) (requiring the physician who administers the vaccines to give a certificate or other documentation to the individual who presented the student for immunization).

202. IND. CODE ANN. § 20-34-4-5 (West 2008).

203. See id.

204. IND. CODE ANN. § 12-17.2-4-18.1 (West 2007).

205. IND. CODE ANN. § 21-40-5-2 (West 2008). 
students. $^{206}$

\section{Secondary immunization efforts: educating the public about VPDs}

State actors may also intervene in the tragedy of the public health commons by educating individuals about the consequences of immunization decisions. ${ }^{207}$ Indiana already incorporates some educational provisions into its immunization laws. For example, middle schools must provide parents of female children entering the sixth grade with information disseminated by the state department of health concerning the link between HPV and cervical cancer. ${ }^{208}$ Indiana also requires its higher educational institutions to provide students intending to enroll with information about the risks of and available vaccination against meningococcal disease. ${ }^{209}$ These provisions directly support public health goals and serve as useful models in considering the incorporation of further educational components into our immunization programs.

\section{Enforcement of mandatory immunization requirements in Indiana}

Schools must report to the state and local health departments data regarding the number of students who have complied with the immunization requirements and the number of students who have not demonstrated their immunity to listed VPDs. ${ }^{210}$ In order to enable and promote enforcement of the immunization mandates, Indiana empowered the state department of health to commence civil actions against schools failing to enforce immunization requirements or to comply with reporting requirements. ${ }^{211}$ The department may even seek a writ of mandamus to compel compliance. ${ }^{212}$ In concert, these provisions allow for the periodic auditing of records, review of established procedures, and corrective actions when the systems stall or fail. Indiana therefore enjoys the statutory and regulatory frameworks necessary to hopefully avoid, but certainly react to, lax enforcement situations like that experienced in Atlanta in $2008 .^{213}$

206. IND. CODE ANN. § 21-40-5-5 (West 2008).

207. See discussion supra Part II.E.2.

208. IND. CODE ANN. § 20-34-4-3(c) (West 2008).

209. IND. CODE ANN. § 21-40-5-5(a) (West 2008).

210. IND. CODE ANN. § 20-34-4-6(a) (West 2008).

211. IND. CODE ANN. $\S 20-34-4-5$ (d) (West 2008) (applying to public schools); IND. CODE ANN. § 21-40-5-8 (West 2008) (applying to postsecondary institutions).

212. See IND. CodE ANN. § 34-27-3-1 (West 1999).

213. See generally Alison Young, Spotlight: Vaccination Law Fails to Touch All Kids, AtlantA J.-Const., Oct. 26, 2008, at A1; Alison Young, Watching Out For Your Safety and Pocketbook, ATLANTA J.-ConST., Nov. 23, 2008, at D1 (describing poor vaccination coverage). 


\section{The mandatory immunization exemptions available to Hoosiers}

In 1900, the Indiana Supreme Court first articulated the authority of the state pursuant to its police power to compel a student to be immunized or excluded during a smallpox outbreak: "[A]mong all of the objects to be secured by governmental laws, none is more important than the preservation of the public health; and an imperative obligation rests upon the state ... to take all necessary steps to promote this object." ${ }^{214}$ The court did qualify the extent of this power: "It is not, however, without limitation, and it cannot be invoked so as to invade the fundamental rights of a citizen."215 Because compelled vaccination could infringe on fundamental rights and autonomy, Indiana provides exemptions in two circumstances.

\section{a. Exemptions in the case of medical contraindication}

First, Indiana observes the limitation suggested by the United States Supreme Court in Jacobson that forced inoculation against medical indications would be "cruel and inhuman to the last degree[,]"216 by statutorily providing for medical exemptions in conjunction with each of its immunization requirement provisions. For example, individuals do not have to undergo vaccination to meet school-entry requirements when "a physician certifies that a particular immunization required . . . is or may be detrimental to a student's health." ${ }^{217}$ The physician's certification serves as an exemption for the duration of the medical contraindication, but should expire when "immunization is found no longer detrimental to the student's health." 218 A similar exemption allows college students to avoid immunization requirements "[i]f a health care provider makes a written statement indicating the nature and probable duration of a medical condition or circumstances that contraindicate an immunization, identifying the specific vaccine that could be detrimental to the student's health."219 Such an exemption endures only for the duration of the contraindication: "If the student's medical condition or circumstances subsequently permit immunization, the exemptions granted by this section terminate and the student shall obtain the immunizations ....,220 The language of both provisions clearly demonstrates the legislature's intent to limit medical exemptions to necessary circumstances.

Unfortunately, reports and records aggregate claimed medical exemp-

214. Blue v. Beach, 56 N.E. 89,92 (Ind. 1900).

215. Id. at 92 (quoting State v. Gerhard, 44 N.E. 469,473 (Ind. 1893)).

216. Jacobson, 197 U.S. at 39.

217. IND. CODE ANN. $§ 20-34-3-3$ (West 2008).

218. Id.

219. IND. CODE ANN. $§ 21-40-5-4$ (West 2008).

220. Id. 
tions at the state level without tracking data regarding the underlying medical contraindications. ${ }^{221}$ Although an exemption may terminate as a matter of law when immunization is no longer contraindicated, ${ }^{222}$ absent frequent review of compliance records, a stale medical exemption will continue to allow the attendance of an unimmunized student despite the lack of a condition justifying the risks she endures and poses. These considerations indicate a potential for abuse of the medical exemption, especially where sufficient data regarding geographic concentrations of medical exemptions or anomalous numbers of exemption certifications produced by specific providers are not tracked.

\section{b. Exemptions in the case of conflicting religious beliefs}

Indiana's other available exemption type allows for the avoidance of vaccinations due to religious conflicts. The language of the religious exemption statutes is broad and lacks common qualifying elements seen in other states: "Except as otherwise provided, a student may not be required to undergo .... immunization ... when the child's parent objects on religious grounds." 223 Notably absent are requirements for the exemptor to aver to the sincerity of her religious beliefs and to describe in detail her faith's conflicting tenets. Rather, in order to secure the exemption, a Hoosier need only make her objection in a signed writing that she delivers to a school official or to the official providing the vaccination. ${ }^{224}$ The statutes also omit any language regarding the evaluation - including the potential denial - of exemption applications.

The phrasing of the religious exemption provisions would seem to allow any parent or student who claims a religious exemption to successfully obtain one. Facially, these statutes do not appear to contemplate a process of application and approval, but rather an unreviewable act of declaration. $^{225}$ Indiana's statutory scheme thus appears excessively permissive, rather than narrowly tailored so as to ensure that the exemptions are only provided to those whose autonomy - in a religious sense - actually would be infringed upon by vaccination mandates. Accordingly, the system allows Hoosiers to secure de facto personal belief exemptions and exemptions of convenience, ${ }^{226}$ in addition to the religious exemptions likely

221. Rudavsky, supra note 93 , at A9.

222. See, e.g., IND. CODE ANN. § 21-40-5-4 (West 2008).

223. InD. CoDE ANN. $\S 20-34-3-2$ (a) (West 2008). See InD. Code ANN. $§ 21-40-5-6$ (West 2008) for essentially identical language involving students at higher education institutions.

224. $\S 20-34-3-2(b) ; \S 21-40-5-6(b)$.

225. Cf. Jones v. Wyoming St. Dep't of Health, 18 P.3d 1181 (Wyo. 2001) (holding that denial of a medical exemption was not permitted under a state law that required only that the applicant claim the exemption and did not provide for discretionary review).

226. See discussion supra Part III.C.3-4. 
contemplated by the legislature.

\section{B. Recommended Changes to Indiana's Mandatory Immunization Provisions}

Having mapped out the current structure of Indiana's mandatory immunization program, including its strengths and infirmities in light of the considerations introduced in preceding sections, the remainder of this Note proposes changes to the program to increase its efficacy. I will begin by discussing the state's strong record of maintaining the Hoosier public health common. I will then propose changes that Indiana's legislators and administrators can easily make to improve on that record while accommodating autonomy interests and assuaging fears.

\section{The current state of vaccination coverage and exemption prevalence}

According to the Indiana State Department of Health, vaccine coverage levels for Hoosier students enrolled in the reporting schools reached ninety-six percent during the most recent year for which data have been published. ${ }^{227}$ The Indianapolis Star recently reported that "[i]n recent years in Indiana, the numbers of medical and religious exemptions have remained stable, at less than 1 percent each."228 If these statistics accurately depict vaccination coverage and the prevalence of claimed exemptions throughout Indiana, then parents, school administrators, and public health authorities have done a remarkable and commendable job furthering the health of Hoosiers and, by extension, communities around the globe.

Unfortunately, these aggregate percentages may camouflage both shortcomings in vaccination coverage in specific schools or communities and also significant increases in exemptions secured. Although every school must annually file written reports with the state and local departments of health, ${ }^{229}$ only "[n]inety-four percent of public schools and sixtyeight percent of private schools reported complete immunization data[,]" and the aggregate report excluded data from schools reporting incomplete data. ${ }^{230}$ These gaps in reporting may fail to capture and depict low levels of vaccine coverage in the schools whose data were not received or analyzed. This oversight may have particular significance due to the likelihood of clusters of unimmunized students within a given community or school. ${ }^{231}$ These unidentified clusters lead to significant risks of outbreak susceptibili-

227. Kristin Ryker, Indiana State Department of Health, 2006-2007 School Year (2007), http://www.in.gov/isdh/21032.htm\#Levels (last visited Mar. 14, 2009).

228. Rudavsky, supra note 95 , at A1.

229. IND. CODE ANN. § 20-34-4-6 (West 2008).

230. Ryker, supra note 227.

231. See Joyner, supra note 183, at 11. 
ty, even where aggregate coverage has been high. ${ }^{232}$ Exemption prevalence, as reported on by The Indianapolis Star, ${ }^{233}$ may likewise be subject to unrealistic characterization when statistics are viewed in aggregate form.

While the exemption percentage may have remained around one percent, the actual number of religious exemptions reported by school systems for children entering kindergarten has more than doubled in recent years. ${ }^{234}$ During the same period, the actual number of children entering kindergarten has varied less than fifteen percent. ${ }^{235}$ Accordingly, a "stable" one percent may yet encompass dramatic increases in exemptions sought, following alarming trends in other states. ${ }^{236}$ Although the aggregate vaccination coverage statistics seem favorable, Indiana's demonstrated susceptibility to outbreaks, ${ }^{237}$ viewed in light of rising anti-vaccine activism throughout the nation, suggests that its mandatory immunization provisions should be revisited and updated. The following minor changes may help Indiana develop and maintain strong levels of vaccine coverage and herd immunity without significantly infringing on individual autonomy, risking unconstitutional waters, or alienating an already distrusting public.

\section{Amending the religious exemption statutory provisions}

As noted above, the ease with which any individual can secure a religious exemption in Indiana threatens to render the entire mandatory immunization scheme merely voluntary. ${ }^{238}$ As more parents distrust public health authorities and the vaccines they advocate, they will be more likely to seek refuge in whatever exemptions are available. Because Indiana's religious exemption provisions allow for exemptions of convenience and de facto philosophical belief exemptions, far more people can successfully avoid immunizations for their children than the legislature likely intended when it enacted the religious exemption provisions.

Assuming the Indiana General Assembly provided for religious exemptions to prevent infringing upon Hoosiers' free exercise of religion in accordance with our State and Federal Constitutions, the exemption should reach only those individuals whose religious faith and practices would be undermined by vaccination mandates. Yet a government can hardly infringe upon beliefs that an individual actually does not hold. The statutory provisions should thus be amended to ensure a narrow tailoring which al-

232. Parker et al., supra note 10 , at 447 .

233. Rudavsky, supra note 95 , at A1.

234. Id. at A9 (reporting an increase from 272 in the 2001-2002 school year to 557 in the 2007-2008 school year).

235. See id. (showing an annual average of 84,034 during this period).

236. See id. at A1; see also Steinhauer, supra note 7, at A1.

237. See, e.g., Parker et al., supra note 10, at 447 (describing a 2005 measles outbreak).

238. See discussion supra Part IV.A.4.b. 
lows religious exemptions, to the greatest degree practicable, only for those with sincerely held beliefs that would actually be infringed upon.

Three easily drafted provisions would enable significant progress toward this goal. First, the exemption should be available only upon the applicant's averring to the sincerity of her religious beliefs in a notarized affidavit. Such a provision could be modeled on the affidavit set forth in the corresponding Delaware statute, which requires statements swearing or affirming a belief in a Supreme Being, affirming the sincerity of the belief, and denying that the belief is derived from "a political, sociological or philosophical view of a merely personal moral code."239

Second, the exemption should be conditioned upon the applicant's attaching a letter or document detailing those specific tenets of faith with which vaccination conflicts. New York provides for such a system in its statutory and regulatory provisions. That state's vaccination mandates do "not apply to children whose parent, parents, or guardian hold genuine and sincere religious beliefs which are contrary to the practices [of immunization]."240 That statute further provides for administrative adoption of "rules and regulations to effectuate [its] provisions and purposes."241 Pursuant to that authority, the New York State Department of Health delegates the power to school officials to require parents seeking a religious exemption to provide supporting documentation. ${ }^{242}$ Indiana should incorporate similar provisions delegating such authority to the state and local departments of health and, ultimately, to local school officials.

Third, either or both of the preceding provisions should be accompanied by a warning regarding a penalty for false swearing. Montana's religious exemption provision simply states: "A person who falsely claims a religious exemption is subject to the penalty for false swearing provided in 45-7-202."243 A similar warning appended to Indiana's religious exemption provisions could discourage disingenuous use of the exemption by promoting honest reflection or evoking fear of reprisal for exploitation of a legal loophole. Care should be taken, however, to ensure that these suggested amendments do not establish or deny exemptions for any particular religion or faction. By drafting the provisions with neutrality toward particular religious beliefs, legislators can likely limit constitutional challenges under the Establishment Clause. ${ }^{244}$

Further, would-be exemptors should be required to apply for religious exemptions instead of simply claiming them by providing letters to caregiv-

239. Del. Code ANN. tit. 14, § 131 (Supp. 2008).

240. N.Y. Public Health LAW $\S 2164(9)$ (McKinney 2002).

241. Id. at $\$ 2164(10)$.

242. N.Y. COMP. CODES R. \& REGS. TIT. 10, § 66-1.3 (2009).

243. MONT. CODE ANN. $\S 20-5-405$ (2007). The referenced penalties include a fine, confinement in jail for up to six months, or both. MONT. CODE ANN. § 45-7-202 (2007).

244. See supra text accompanying note 164 . 
ers or school officials. This would afford an opportunity for state supervision of religious exemption approvals. The amended statutes could identify the agency or agencies authorized to receive, review, and grant exemption applications, preferably even delegating authority to those agencies to deny fraudulent applications and providing for both administrative and judicial review for denied applicants. The agencies receiving this delegated authority could then promulgate regulations describing the methods of evaluation and the minimum standards for approval, thus informing the public of the means for securing a desired exemption and appealing a denied application. Yet even without the legislature creating denial authority or the exercise of such authority, the added complexity afforded by the three suggested provisions will likely discourage the use of the religious exemption for convenience or for de facto personal belief exemptions based on feigned religious beliefs. ${ }^{245}$ By contrast, where parents or college students have genuine religious beliefs which conflict with immunization practices, they would likely be undaunted by an administrative application procedure with de minimis costs. Accordingly, these simple statutory amendments would allow the state to intervene and prevent a portion of the behavior leading to the tragedy of the public health common without additional infringement on the free exercise of religion.

\section{Advocating the taboo: incorporating philosophical exemptions}

Most advocates of childhood vaccination and mandatory immunization programs vehemently oppose the allowance of philosophical or personal belief exemptions. ${ }^{246}$ My suggested modifications of Indiana's religious exemption provisions would likely curtail the would-be exemptor's ability to secure a religious exemption based on philosophical grounds alone. Yet the constitutional demarcation between religious and philosophical beliefs is decidedly unclear, ${ }^{247}$ opening up to litigation any denial of a religious exemption due to its philosophical (as opposed to religious) foundation. More worrisome is the possibility that allowing religious exemptions and denying philosophical exemptions is of itself unconstitutional. While not permitting any non-medical exemption appears constitutionally sound, ${ }^{248}$ if

245. See Rota et al., supra note 75 , at 647 .

246. See, e.g., Mobeen H. Rathore, Op.-Ed., Vaccines Key to Health, SUN SENTINEL (Fort Lauderdale), Nov. 23, 2008, at 4F ("All concerned citizens should write their state legislators and the governor and ask them to prevent any efforts to place our children at risk by weakening childhood vaccination programs. ..."). See also Offit, supra note 37, at A10 ("[A]s anti-vaccine activists continue to push more states to allow for easy philosophical exemptions, more and more children will suffer and occasionally die from vaccinepreventable diseases.").

247. See supra note 178 and accompanying text.

248. See Brown v. Stone, 378 So.2d 218 (Miss. 1979), cert. denied, 449 U.S. 887 (1980) 
not inherently reasonable, ${ }^{249}$ permitting religious exemptions while denying those based on personal beliefs may run afoul of the Establishment Clause and the Fourteenth Amendment. ${ }^{250}$

Hoosier politicians may be reluctant to present the image of abandoning genuine public health interests by instituting a de jure philosophical belief exemption. But such an action would not necessarily undermine Indiana's mandatory vaccination programs. First, de facto personal belief exemptions are already possible in Indiana. ${ }^{251}$ Establishing a de jure exemption - with requirements for averment of sincerity and detailed explanation of the basis of personal objections - may actually decrease the use of personal belief exemptions from the status quo.

Second, the inclusion of an "informed refusal" provision can ensure that parents at least receive information regarding the relative risks and the socio-economic impacts involved in the decision not to vaccinate, ${ }^{252}$ thus reducing the likelihood of a dangerous and unnecessary proliferation of exemptions. Arizona, for example, allows an unvaccinated student to attend school if her parent "submits a signed statement to the school administrator stating that [he or she] has received information about immunizations provided by the department of health services and understands the risks and benefits of immunizations and the potential risks of nonimmunization . . ..,253 Indiana could incorporate an informed refusal provision ranging from the simple - requiring parents to review and sign a vaccination information brochure in the presence of a health care professional - to the complex - requiring attendance at a public seminar held by the local health department that presents similar information and holds a question and answer session. These educational efforts may help change the minds of individuals who would otherwise secure exemptions, thus helping to prevent the tragedy of the public health common.

Third, allowing for personal belief exemptions may in fact engender trust for government authorities in the general public through a formal recognition of the importance of individual autonomy. Combined with the educational aspects of informed refusals, this step may reduce the belief held by some constituents that government authorities are in collusion with vaccine manufacturers. Continuing to prevent those genuinely opposed to vaccinations from receiving relief through an exemption only serves to "ex-

249. See Offit, supra note 37, at A10 ("We don't allow philosophical exemptions to restraining young children in car seats, to smoking in restaurants or to stopping at stop signs.").

250. See supra notes $154-60$ and accompanying text for discussion regarding the potential for political entanglement with religion to violate the Establishment Clause and the possible equal protection violations from disparate treatment of the religious and secular.

251. See discussion supra Part IV.A.4.b.

252. For a succinct and clear introduction to the concept of informed refusal in the immunization context, see Silverman, supra note 6, at 294.

253. Ariz. ReV. Stat. ANN. § 15-873 (West Supp. 2008). 
acerbate feelings of animosity and skepticism toward vaccination and the public health system in general." 254

The General Assembly can establish such a personal belief exemption by converting the religious exemption statutory provisions to general sincerely-held belief exemptions without reference to the source of those beliefs. ${ }^{25}$ Such an amendment would allow state authorities to successfully navigate "the channel between the Scylla and Charybdis ... in order to survive constitutional scrutiny."256 The resulting exemption provisions would likely be immune to challenges under the Establishment and Free Exercise Clauses while simultaneously increasing the palatability of the state's mandatory immunization program by allowing for limited relief where the program may significantly infringe upon individual autonomy. Making the process of obtaining the exemptions arduous, but not prohibitive, will avoid the demonstrated deleterious effects of affording personal belief exemptions on immunization coverage.

\section{Revisions of mandatory immunization reporting requirements}

Part of the difficulty of tracking the impacts of exemptions from immunization requirements arises from the way in which data regarding exemptions are gathered and maintained. Data aggregation at the state level masks geographic differences in vaccination coverage within communities. ${ }^{257}$ When the data do not distinguish between reasons for medical exemptions, or even between medical and non-medical exemptions, their value for epidemiological analysis is compromised. In order to monitor exemption impacts on VPD trends, state agencies must begin tracking exemptions with more detail.

Reports of medical exemptions should include the health care provider from whom the exemption originates, so that statistical aberrations - such as an unusually high number of exemptions from one provider or facility can alert local or state authorities to the possibility of abuse. Medical exemption reports should also include the nature of the underlying cause, if only to the level of permanent (e.g., allergies) or temporary (e.g., injuries or infections) contraindications. This information would allow public health authorities to assess the efficacy of annual reviews at the local level and would enable officials to enforce immunization requirements for exemptions that expire by law. ${ }^{258}$ Finally, the data should be collected and preserved for analysis at the county level, allowing public health authorities to recognize dangerous pockets of unvaccinated populations within the state.

254. Silverman, supra note 6, at 293.

255. See, e.g., CAL. HeAlth \& SAFETY CODE $\S 120365$ (West 2006).

256. Thomas, 450 U.S. at 721 (Rehnquist, J., dissenting).

257. See supra text accompanying notes 183-85.

258. See IND. CODE ANN. $§ ~ 21-40-5-4$ (West 2008). 
In addition, agencies should, pursuant to authority granted in the amended exemption statutes, establish rules requiring periodic renewal of all exemptions. Periodic renewal would serve two complementary purposes. First, it would ensure that temporary medical exemptions expire as contemplated by statute, ${ }^{259}$ thus promoting the vaccination of students for whom immunizations are no longer contraindicated. Second, the benefits of increased complexity in the exemption application process would be multiplied with each iteration of expiration.

\section{Attempting to internalize the negative externalities of immunization ex- emption}

Independent of an individual's sincere aversion to vaccinations or conflicting religious beliefs, the current structure of Indiana's mandatory immunization program provides incentives for parents to avoid immunization through exemption. Because of Indiana's high level of vaccination coverage, ${ }^{260}$ a family within a community can enjoy the benefits of herd immunity without having to actively participate in immunization programs. By opting for exemption over vaccination, the individual avoids the potential adverse effects of vaccinations as well as the costs and burdens of receiving the vaccinations. The exemptor internalizes these benefits while externalizing to the community at large the detriments of decreased herd immunity and increased possibility of transmission. Indiana should consider enacting provisions that at least partially remove these discrepancies between exemptors and participants in order to decrease the number of exemptions sought.

One method would be to estimate the total financial cost of complying with the mandatory vaccination schedule and to place this price upon exemption applicants as a processing fee. To avoid the implication of disparate treatment, the reviewing agency could refund this nominal processing fee if it denies the application. This system would reduce or remove the financial incentive to choose exemption over compliance with the vaccination schedule. It could also simultaneously reduce the possibility of the availability of exemptions violating the Establishment Clause of the First Amendment or the Equal Protection Clause of the Fourteenth Amendment. ${ }^{261}$ The revenue, albeit likely of minor scope, could be used to fund the educational initiatives of an informed refusal requirement or to defray the costs of administrative review of exemption applications and periodic records audits at schools and child care facilities.

An equally effective alternative would be to fully subsidize the cost of

260. See Ryker, supra note 227.

261. See discussion supra notes 154-60 and accompanying text. 
all vaccinations administered to children in Indiana. ${ }^{262}$ While the requisite tax increase would likely engender public opposition, and therefore legislative reluctance, the proposal could be accompanied by a promotion campaign detailing the underlying rationale and cost considerations. Because every Hoosier benefits from a high level of vaccination coverage, every Hoosier should share in the costs necessary to attain that coverage and its resulting herd immunity. Such a publicly-funded system would redistribute the financial burden of immunizations to all individuals while simultaneously reducing the risk of large-scale expenditures that could result from outbreaks among unvaccinated individuals. ${ }^{263}$ It would also effectively remove the financial incentive component of decisions to seek exemption from vaccination requirements, thus altering the rationale justifying decisions that would promote the tragedy of the public health common.

\section{CONCLUSION}

In the past, VPDs wreaked havoc throughout the United States. Through state-implemented mandatory immunization programs, morbidity and mortality resulting from infectious diseases plummeted and some VPDs have been completely or nearly eradicated. Because of the continuing threat of reintroduction, however, states must remain vigilant to prevent VPD outbreaks and enable eradication. While mandatory childhood immunization remains the most efficacious method for combating VPDs, parents fearing the adverse effects of vaccinations increasingly resist mandatory immunizations. The simple modifications to Indiana's mandatory immunization program proposed in this Note would allow the state to continue promoting public health while simultaneously addressing parental misgivings and recognizing the fundamental importance of individual autonomy. By establishing a program that aggressively enforces immunization mandates, but also allows for well-considered exemptions, Indiana can become a national leader in preventing the tragedy of the public health common.

262. Currently vaccines are only available free of charge to the children of parents unable to afford vaccinations. IND. CODE ANN. § 20-34-4-4 (West 2008).

263. See supra text accompanying notes 55-58. 